\title{
Faktor-Faktor yang Mempengaruhi Penggunaan Sistem E-audit Pada Badan Pemeriksa Keuangan Republik Indonesia Perwakilan Provinsi Sulawesi Utara
}

\author{
PRICILIA JOICE PESAK ${ }^{1}$, JULLIE J. SONDAKH ${ }^{2}$, HENDRIK GAMALIEL ${ }^{3}$
}

\author{
Program Studi Magister Akuntansi Fakultas Ekonomi dan Bisnis Universitas Sam Ratulangi \\ Email: prispesak@gmail.com ${ }^{1}$, julliesondakh@gmail.com ${ }^{2}$, hendrik_gamaliel@unsrat.ac.id ${ }^{3}$
}

\begin{abstract}
This study aims to analyze factors that influence usage of e-Audit system in Badan Pemeriksa Keuangan Republik Indonesia Perwakilan Provinsi Sulawesi Utara using techonology acceptance model (TAM). This study was conducted on auditors who have been using e-Audit system. This is a quantitative research with structural relationship approach. Data were obtained by questionnaires which were distributed to 60 auditors of BPK RI Perwakilan Provinsi Sulawesi Utara and documentation study. The data were analysed by Partial Least Square Structural Equation Model (PLS-SEM) and used SmartPLS software 3.2.7 The results of the study indicate that the factors that influence the use of the e-Audit system are external variables of characteristics system relevant through perceived usefulness, terminology through perceived ease of use, perceived usefulness, attitude using the e-Audit system and behavioral intentions using the e-Audit system. On the other hand, perceived ease of use is found to be a factor that does not affect the actual use or use of e-Audit system.
\end{abstract}

Keywords: e-Audit System, Technology Acceptance Model (TAM).

\begin{abstract}
Abstrak. Penelitian ini bertujuan menganalisis faktor-faktor yang mempengaruhi penggunaan sistem $e$-Audit pada Badan Pemeriksa Keuangan (BPK) Republik Indonesia (RI) Perwakilan Provinsi Sulawesi Utara dengan menggunakan Techonology Acceptance Model (TAM). Penelitian ini dilakukan pada auditor BPK yang menggunakan sistem $e$-Audit. Metode penelitian yang digunakan adalah metode penelitian kuantitatif dengan pendekatan survei bersifat hubungan struktural. Data diperoleh melalui kuesioner yang dibagikan kepada 60 auditor BPK RI Perwakilan Provinsi Sulawesi Utara dan studi dokumentasi. Alat analisis data yang digunakan dalam penelitian ini adalah Partial Least Square Structural Equation Model (PLS-SEM), dengan bantuan perangkat lunak SmartPLS 3.2.7. Hasil penelitian menunjukkan bahwa faktor-faktor yang berpengaruh terhadap penggunaan atau pemakaian sesungguhnya sistem $e$-Audit adalah variabel eksternal karakteristik sistem relevan melalui kegunaan persepsian, variabel eksternal karakteristik sistem terminologi melalui kemudahan penggunaan persepsian, kegunaan persepsian, sikap menggunakan sistem $e$-Audit dan niat perilaku menggunakan sistem $e$-Audit. Sedangkan, faktor yang tidak berpengaruh terhadap penggunaan atau pemakaian sesungguhnya sistem $e$-Audit adalah kemudahan penggunaan persepsian.
\end{abstract}

Kata Kunci: sistem e-Audit, Technology Acceptance Model (TAM).

\section{Pendahuluan}

Reformasi birokrasi pada hakikatnya merupakan upaya untuk melakukan pembaharuan. Pembaharuan yang dimaksud berkaitan dengan perubahan mendasar terhadap sistem penyelenggaraan pemerintahan terutama menyangkut aspek-aspek kelembagaan (organisasi), ketatalaksanaan (proses bisnis) dan sumber daya manusia aparatur. Reformasi birokrasi dilaksanakan dalam rangka mewujudkan tata kelola pemerintahan yang baik (good governance). Dengan kata lain, reformasi birokrasi adalah langkah strategis untuk membangun aparatur Negara agar lebih berdaya guna dan berhasil guna dalam mengemban tugas umum pemerintahan dan pembangunan nasional (Kementerian Pendayagunaan Aparatur Negara dan Reformasi Birokrasi, 2019).

Berdasarkan Peraturan Presiden Republik Indonesia Nomor 81 Tahun 2010 tentang Grand Design Reformasi Birokrasi 2010-2025, tujuan Grand Design reformasi birokrasi untuk memberikan arah kebijakan pelaksanaan reformasi birokrasi nasional selama kurun waktu 2010-2025. Dengan adanya Peraturan Presiden tersebut, reformasi birokrasi di kementerian/lembaga dan Pemerintah Daerah dapat berjalan secara efektif, efesien, terukur, konsisten, terintegrasi, melembaga dan berkelanjutan.

Badan Pemeriksa Keuangan (BPK) melaksanakan reformasi birokrasi dengan mengacu pada UUD 1945 dan Peraturan Pemerintah yang tersebut diatas. Salah satu perbaikan yang dilakukan di 
lingkungan internal BPK adalah dengan memasukkan penerapan sistem e-Audit dalam Rencana Strategis (Renstra) BPK 2011-2015. Sistem e-Audit dipilih sebagai inovasi yang memanfaatkan kemajuan teknologi, karena adanya kesenjangan yang besar antara jumlah entitas pemeriksaan dan sumber daya BPK, dalam hal ini pemeriksa atau auditor. Adanya kesenjangan tersebut menyebabkan pemeriksaan berjalan tidak efektif dan efesien. Dengan adanya sistem $e$-Audit, diharapkan pemeriksaan dapat berjalan dengan efektif dan efesien (Purnomo, 2011).

Sistem $e$-Audit adalah sistem pengawasan melalui pusat data BPK yang menggabungkan data elektronik BPK (e-BPK) dengan data elektronik pihak yang diperiksa (e-Auditee) agar BPK dapat melakukan perekaman, pengolahan, pertukaran, pemanfaatan dan monitoring data yang bersumber dari berbagai pihak dalam rangka melakukan pemeriksaan atas pengelolaan keuangan Negara. Untuk menghubungkan $e$-BPK dan e-Audite BPK menggunakan strategi Link and Match. Dengan fitur matching ini, akan terlihat keterkaitan antara entitas yang satu dengan entitas yang lain. Penerapan sistem e-Audit ini diharapkan dapat mempermudah pemeriksaan, meningkatkan efesiensi dan efektivitas pemeriksaan (Purnomo, 2011).

Dalam mendukung pelaksanaan penerapan $e$-Audit, perwakilan BPK RI Sulut pada tahun 2011 telah melaksanakan sosialisasi kepada pegawai BPK RI tentang reformasi birokrasi, renstra, $e$ Audit dan jabatan fungsional. Pada tahun 2012, BPK RI perwakilan Sulut telah melakukan penandatangan nota kesepahaman dengan 16 pemerintah daerah se-provinsi Sulut dan telah dilakukan piloting atau uji coba $e$-Audit (Purnomo, 2012). Pada tahun 2015 e-Audit secara efektif diterapkan BPK RI perwakilan Provinsi Sulut, namun saat ini penerapan sistem $e$-Audit belum $100 \%$. Penerapan sistem e-Audit masih sebatas konfirmasi ke entitas pemeriksaan atau pihak ketiga, contohnya maskapai penerbangan untuk mengkonfirmasi perjalanan dinas. Penerapan sistem $e$-Audit yang belum $100 \%$ menyebabkan tujuan adanya $e$-Audit untuk pemeriksaan yang efektif dan efesien, belum tercapai. Oleh karena itu, perlu untuk diteliti tentang faktor-faktor yang mempengaruhi penggunaan sistem $e$-Audit.

Model penerimaan teknologi (Technology Acceptance Model) atau TAM dalam Davis (1993), didefinisikan sebagai salah satu model yang dibangun untuk menganalisis dan memahami faktorfaktor yang mempengaruhi diterimanya penggunaan teknologi informasi. TAM didasarkan pada model TRA (Theory of Reasoned Action), ini dikembangkan oleh Davis (1989). Model TRA menjelaskan bahwa perilaku seseorang didorong oleh sikap dan niat seseorang untuk melakukannya. TAM menambahkan dua faktor utama pada model TRA, yaitu kegunaan persepsian (perceived usefulness) dan kemudahan penggunaan persepsian (perceived ease of use). Menurut TAM dua faktor tersebut menentukan penerimaan individu terhadap sistem teknologi informasi (Hartono, 2007:111).

TAM dipilih sebagai dasar teori dalam penelitian ini, karena model TAM sebagai teori yang dapat digunakan untuk menjelaskan faktor-faktor yang mempengaruhi pemakaian $e$-Audit oleh penggunanya. Dalam TAM ada lima faktor yang mempengaruhi penggunaan teknologi sistem informasi (actual system use) yaitu variabel eksternal, kegunaan persepsian (perceived usefulness), kemudahan penggunaan persepsian (perceived ease of use), sikap menggunakan sistem informasi (attitude towards using information system), niat perilaku menggunakan sistem informasi (behavioral intention to use information system). Oleh karena itu, TAM akan membantu menjelaskan faktor-faktor apa saja yang mempengaruhi penggunaan $e$-Audit oleh auditor BPK RI Perwakilan Provinsi Sulawesi Utara.

David (2013) menganalisis penerimaan e-Audit ditinjau dari kemudahan penggunaan persepsian (perceived ease of use) dan kegunaan persepsian (perceived usefulness). Akan tetapi, David (2013) tidak menganalisis variabel eksternal yang mempengaruhinya dan pemakaian sesungguhnya sistem $e$-Audit. David (2013) melakukan penelitian sebelum sistem $e$-Audit diterapkan pada tahun 2015, sehingga David (2013) meneliti tentang penerimaan sistem e-Audit. Selain itu, David (2013) melakukan penelitian di BPK RI dengan jumlah sampel 200 auditor. Dalam penelitian ini, peneliti akan menganalisis penggunaan $e$-Audit merujuk pada penelitian David (2013), namun menambahkan variabel eksternal yaitu karakteristik sistem: relevan (relevance), terminologi (terminology) dan desain layar (screen design) serta pemakaian sesungguhnya (actual system use).

Menurut Hartono (2007:126) karakteristik sistem dikategorikan sebagai variabel karakteristik tugas. Dalam TAM variabel eksternal dikategorikan dalam empat kategori, yaitu variabel individu, 
organisasi, kultur dan karakteristik-karakteristik tugas (Hartono, 2007:124). Karakteristik tugas merupakan sifat dari tugas teknologi sistem informasi sebagai kebutuhan perilaku untuk menyelesaikan tujuan yang sudah ditentukan, melalui beberapa proses dan menggunakan informasi yang telah disediakan (Hartono, 2008:495). Karakteristik sistem menurut Hartono (2005:3) merupakan suatu sistem yang memiliki sifat-sifat tertentu, yaitu komponen-komponen, batas sistem, lingkungan sistem, penghubung (interface), masukan, keluaran, pengolah, sasaran dan tujuan. Relevan, terminologi dan desain layar dipilih sebagai karakteristik sistem untuk penelitian ini karena sistem $e$-Audit merupakan sistem informasi pencarian informasi. Sistem $e$-Audit merupakan pusat data yang berisi informasi baik dari BPK maupun dari entitas yang diperiksa (Purnomo, 2011), sehingga relevan sebagai komponen, serta terminologi dan desain layar sebagai penghubung (antarmuka) menjadi faktor penting yang harus diperhatikan dalam sistem informasi pencarian informasi (Hong, Thong, Wong dan Tham , 2002).

Penambahan variabel eksternal dan pemakaian sesungguhnya karena penelitian dilakukan setelah sistem $e$-Audit diterapkan. Berdasarkan penelitian sebelumnya (Hong et al, 2002 dan Darsono, 2005), salah satu variabel eksternal yang mempengaruhi kegunaan persepsian (perceived usefulness) dan kemudahan penggunaan persepsian (perceived ease of use) adalah karakteristik sistem. Menurut Hong et al (2002), karakteristik sistem diakui sebagai variabel eksternal yang mempengaruhi penggunaan sistem informasi yang baru melalui kegunaan persepsian dan kemudahan penggunaan persepsian.

Tujuan diadakannya penelitian ini untuk: 1) meneliti faktor-faktor yang mempengaruhi penggunaan sistem e-Audit dengan menggunakan model Technology Acceptance Model (TAM); 2) meneliti hubungan antar variabel di dalam TAM untuk memprediksi penerimaan teknologi oleh para auditor yang sudah pernah menggunakan sistem $e$-Audit.

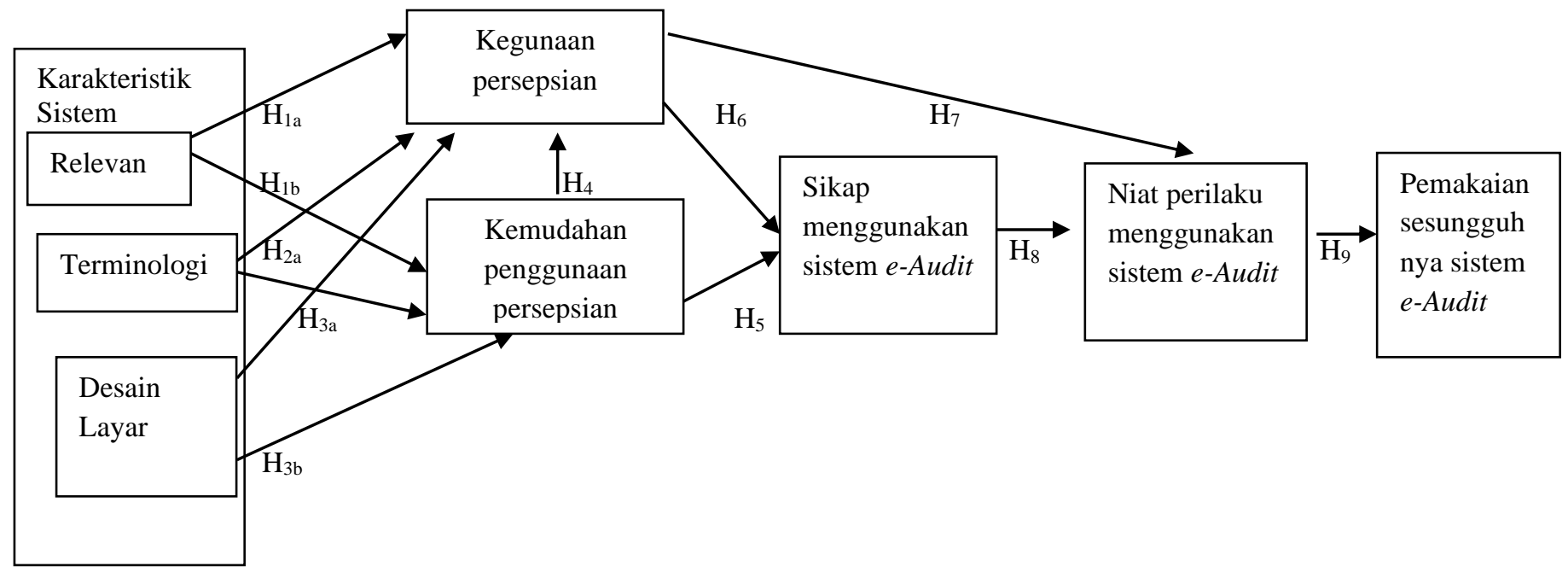

Gambar 1. Kerangka Konseptual

Menurut Davis (1989), variabel eksternal karakteristik sistem berpengaruh terhadap kegunaan persepsian (perceived usefulness) dan kemudahan penggunaan persepsian (perceived ease of use), yang secara tidak langsung berpengaruh terhadap perilaku seseorang untuk menggunakan sistem informasi. Karakteristik sistem sebagai variabel eksternal, akan mempengaruhi minat individual untuk menggunakan teknologi informasi melalui kegunaan persepsian, kemudahan penggunaan persepsian dan sikap. Menurut Hartono (2007:183), karakteristik sistem adalah relevan (relevance), terminologi (terminology) dan desain layar (screen design). Relevan merupakan kesesuaian informasi yang ada dalam sistem informasi dengan tugas-tugas yang harus dilakukan dengan menggunakan teknologi. Terminologi dihubungkan dengan kata-kata, kalimat-kalimat dan singkatan-singkatan yang digunakan dalam sistem teknologi. Desain layar menunjukkan cara informasi ditampilkan di layar.

Hong et al (2002) mengatakan bahwa relevan berpengaruh positif terhadap kegunaan persepsian dan kemudahan penggunaan persepsian berarti, teknologi sistem informasi menyediakan 
dokumen-dokumen yang relevan dengan pengguna atau sesuai dengan kebutuhan pengguna. Ketika teknologi sistem informasi menyediakan informasi yang relevan dengan apa yang dicari oleh pengguna, maka akan memudahkan pengguna untuk menemukan apa yang mereka butuhkan.

Hong et al (2002) berpendapat bahwa teknologi sistem informasi yang berfungsi sebagai sistem pencarian informasi harus memperhatikan terminologi yang ada dalam sistem teknologi tersebut. Kosakata yang digunakan pengguna untuk mengungkapkan kebutuhan informasi mereka sering berbeda dari terminologi penyedia informasi. Perbedaan tersebut, bukan hanya mempersulit pengguna dalam menggunakan teknologi sistem informasi, tetapi juga mengurangi manfaat yang diberikan oleh suatu teknologi sistem informasi. Menurut Darsono (2005), pengetahuan pengguna tentang terminologi dari suatu teknologi sistem informasi akan meningkatkan atau mengurangi manfaat yang diberikan oleh teknologi sistem informasi tersebut.

Para peneliti sistem informasi mengakui bahwa desain antarmuka dan presentasi informasi dari suatu sistem teknologi informasi berpengaruh secara signifikan terhadap strategi dan kinerja pengguna sistem informasi tersebut (Lim et al, 1996). Desain layar bagi sistem pencarian informasi dilaporkan, sama pentingnya dengan sebuah mesin dalam mempengaruhi kinerja suatu sistem informasi (Marchionini et al, 1998). Menurut Hong et al (2002), desain layar yang baik dapat menciptakan lingkungan virtual yang nyaman. Kenyamanan virtual akan membuat pengguna dengan mudah menentukan fungsi dari sistem teknologi informasi.

Kemudahan penggunaan persepsian merupakan suatu kepercayaan untuk pengambilan keputusan. Jika seseorang merasa percaya bahwa sistem informasi mudah untuk digunakan maka akan meningkatkan kepercayaan seseorang akan kegunaan sistem informasi tersebut. Sebaliknya, jika seseorang merasa tidak percaya bahwa sistem informasi mudah untuk digunakan maka kepercayaan seseorang akan kegunaan sistem informasi tersebut akan menurun. Menurut Davis (1989) dalam teori TAM, kemudahan penggunaan persepsian berpengaruh terhadap kegunaan persepsian. Lu et al (2005) mengatakan bahwa kemudahan penggunaan persepsian berpengaruh positif terhadap kegunaan persepsian. Hal ini berarti, kemudahan penggunaan persepsian merupakan faktor penting dalam mengevaluasi kegunaan sistem teknologi.

Menurut Davis (1989), kemudahan penggunaan persepsian merupakan tingkatan dimana seseorang berharap penggunaan sistem teknologi informasi akan bebas dari usaha. Kemudahan penggunaan persepsian berpengaruh positif tergadap sikap menggunakan teknologi informasi (attitude towards using technology information system).

Karpriana (2013) mengatakan bahwa faktor penerimaan kemudahan penggunaan persepsian memiliki pengaruh yang signifikan terhadap sikap pengguna untuk menggunakan suatu sistem informasi, hal ini dapat dijelaskan bahwa semakin tinggi tingkat kemudahan suatu sistem informasi maka akan semakin membentuk perasaan yang positif yang direfleksikan melalui sikap yang positif. Menurut Cahyaning (2016) apabila suatu sistem semakin mudah digunakan maka penerimaan pengguna akan sistem teknologi informasi itu akan semakin baik.

Menurut Davis (1989), kegunaan persepsian adalah ukuran kepercayaan seseorang tentang pengaruh penggunaan teknologi sistem informasi terhadap peningkatan kinerja pekerjaannya. Lebih lanjut menurut Davis (1989), kegunaan persepsian merupakan faktor yang paling dominan dalam mempengaruhi pengguna menentukan sikap dalam penggunaan suatu sistem. Hartono (2007:114) berpendapat bahwa kegunaan persepsian merupakan suatu kepercayaan dalam pengambilan keputusan. Jika seseorang merasa percaya bahwa sistem informasi berguna maka ia akan menggunakannya. Sebaliknya, jika seseorang merasa tidak percaya bahwa sistem informasi berguna maka ia tidak akan menggunakannya.

David (2013) berpendapat bahwa faktor penerimaan teknologi kegunaan persepsianmemiliki pengaruh yang signifikan terhadap sikap untuk menggunakan sistem teknologi informasi. Hal ini berarti, semakin tinggi kegunaan suatu sistem informasi maka akan semakin membentuk perasaan yang positif yang direfleksikan melalui sikap yang positif. Responden menganggap penggunaan suatu sistem informasi bermanfaat sehingga memunculkan sikap positif terhadap penggunaan sistem tersebut.

Menurut Hartono (2007:114), kegunaan persepsian merupakan konstruk yang paling mempengaruhi sikap, niat perilaku dan pemakaian sesungguhnya di dalam menggunakan teknologi 
dibandingkan dengan konstruk yang lain. Menurut Surachman (2013), hal ini mengimplikasikan, bahwa semakin tinggin manfaat yang diambil pengguna, maka semakin tinggi niat pengguna untuk menggunakan suatu sistem informasi. Pengguna merasa yakin bahwa penggunaan suatu sistem informasi akan meningkatkan produktivitas seseorang. Permana (2013) berpendapat bahwa berpengaruhnya kegunaan persepsian terhadap niat perilaku pengguna untuk menggunakan suatu sistem informasi menunjukkan bahwa suatu sistem informasi tersebut diterima.

Davis (1989) mendefinisikan sikap terhadap perilaku sebagai perasaan positif atau negatif seseorang untuk melakukan perilaku tertentu. Sikap untuk menggunakan teknologi sistem informasi sebagai suatu tingkat penilaian terhadap dampak yang dialami seseorang bila menggunakan suatu sistem tertentu dalam pekerjaannya. Menurut Mathieson (1991), sikap menggunakan suatu sistem informasi adalah evaluasi dari pemakai tentang ketertarikkannya menggunakan sistem informasi. Menurut Hartono (2018:116), sikap untuk menggunakan teknologi sistem informasi berpengaruh terhadap niat perilaku untuk menggunakan teknologi sistem informasi.

Menurut El-Gayar dan Moran (2007), pengaruh sikap untuk menggunakan teknologi informasi lebih kuat dibandingkan dengan pengaruh kegunaan persepsian terhadap niat perilaku untuk menggunakan teknologi informasi. David (2013) berpendapat bahwa penerapan sistem e-Audit di BPK mengharuskan para auditor BPK untuk menjalankan sistem tersebut. Dengan adanya kewajiban ini akan meningkatkan niat perilaku auditor untuk menjalankan sistem $e$-Audit.

Davis (1989) menyatakan bahwa pemakaian sesungguhnya merupakan kondisi nyata penggunaan sistem informasi yang dikonsepkan dengan frekuensi dan durasi waktu penggunaan teknologi sistem informasi. Dalam teori TAM, dijelaskan bahwa niat perilaku memiliki pengaruh yang signifikan terhadap pemakaian sesungguhnya. Niat perilaku merupakan prediksi yang baik dari penggunaan teknologi oleh pemakai sistem (Hartono, 2007:116).

Gardner dan Amoroso (2004) mengatakan niat perilaku merupakan ukuran kekuatan niat seseorang untuk melakukan perilaku (penggunaan) tertentu. Niat perilaku adalah peramal yang baik dari pemakaian sesungguhnya suatu teknologi informasi. Intan (2014) berpendapat bahwa sebuah sistem yang mudah dan mampu memberikan manfaat terhadap seseorang tentunya akan menimbulkan niat yang positif terhadap sistem tersebut sehingga akan berimplikasi pada penggunaan sistem dalam intensitas dan frekuensi yang tinggi.

\section{MetodePenelitian}

Jenis penelitian yang digunakan dalam penelitian ini adalah penelitian kuantitatif metode survei bersifat hubungan struktural. Penelitian ini menggunakan data primer dan data sekunder, dengan tujuan untuk menguji hipotesa antara satu variabel independen dengan beberapa variabel dependen. Teknik analisis yang digunakan dalam penelitian ini adalah Partial Least Square Structural Equation Model (PLS-SEM).

Populasi dari penelitian ini adalah auditor atau pemeriksa di Badan Pemeriksa Keuangan Republik Indonesia Perwakilan Provinsi Sulawesi Utara yang berjumlah 60 orang. Jumlah sampel dalam penelitian ini adalah 60 orang dengan pertimbangan 10 kali parameter. Parameter yang dimaksud adalah jumlah variabel yang digunakan.

\section{Hasil dan Pembahasan}

Data dalam penelitian ini adalah data primer yang bersumber dari pengisian kuesioner oleh responden. Responden dalam penelitian ini adalah auditor Badan Pemeriksa Keuangan (BPK) Republik Indonesia Perwakilan Provinsi Sualwesi Utara sebanyak 60 auditor. Kuesioner diantar langsung oleh peneliti di kantor BPK RI Perwakilan Provinsi Sulawesi Utara dan dibantu oleh salah satu staf bagian umum dari BPK RI Perwakilan Provinsi Sulawesi Utara. Hal ini untuk mengantisipasi terjadinya respond rate yang rendah pada saat pengembalian kuesioner.

Analisis data menggunakan SEM-PLS terdiri atas dua langkah. Langkah pertama adalah untuk melihat validitas dan reliabilitas alat ukur yang dimanifestasikan oleh data yang dikumpulkan. Tahap berikutnya adalah menganalisis data sesuai dengan hipotesis yang diajukan. Tahap pertama disebut dengan pengujian model pengukuran (measurement model) dan tahap kedua disebut dengan pengujian model struktural (structural model). 
Ukuran yang paling penting dalam model pengukuran adalah reliabilitas gabungan atau konsistensi internal, validitas konvergen, dan validitas determinan. Konsistensi internal adalah kriteria pertama untuk menguji model pengukuran reflektif untuk melihat nilai reliabilitas ditingkat konstruk (Santosa, 2018:205). Konsistensi internal biasanya diukur dengan menggunakan reliabilitas gabungan (composite reliability). Menurut Santosa (2018:82) nilai konsistensi internal ada pada kisaran 0 dan 1, paling minimal nilai konsistensi internal 0,7 dengan makin tinggi nilai konsistensi internalnya menunjukkan makin tinggi tingkat reliabilitas alat ukurnya. Validitas konvergen adalah ukuran yang menunjukkan sejauh mana sebuah indikator berkorelasi positif terhadap indikator lain pada konstruk yang sama. Nilai validitas konvergen diukur dengan menggunakan average variance extracted (AVE). Menurut Santosa (2018:83), nilai AVE sebesar 0,5 atau lebih menunjukkan bahwa konstruk menjelaskan lebih dari separuh varians memang berasal dari indikator-indikatornya. Validitas diskriminan adalah ukuran yang menunjukkan bahwa sebuah konstruk berbeda dengan konstruk lain.

Validitas diskriminan perlu diuji pada tingkat indikator dan tingkat konstruk. Validitas diskriminan pada level indikator disebut dengan cross loading. Santosa (2018) menyatakan bahwa nilai outer loading dari sebuah indikator untuk suatu konstruk, misalnya A, harus lebih besar dari nilai outer loading indikator tersebut ke konstruk yang lain, misalnya B. Menurut Santosa (2018) nilai minimal outer loading untuk semua indikator adalah 0,7.Menurut Santosa (2018) nilai outer loading antara 0,6-0,7 masih dapat diterima. Ditingkat konstruk, validitas diskriminan diuji dengan membandingkan akar nilai AVE sebuah konstruk dengan korelasi konstruk tersebut dengan konstrukkonstruk yang lain. Menurut Santosa (2018) nilai akar AVE, yang dilihat dari Fornell-Larcker Criterion untuk setiap konstruk lebih besar dibanding dengan nilai korelasi suatu konstruk dengan konstruk lain.

Hasil uji konsistensi internal menunjukkan bahwa nilai composite reliability untuk relevan sebesar 0,862, terminologi sebesar 0,960, desain layar sebesar 0,962, kemudahan penggunaan persepsian sebesar 0,921 , kegunaan persepsian sebesar 0,936 , sikap untuk menggunakan sistem $e$ Audit sebesar 0,857, niat perilaku menggunakan sistem e-Audit sebesar 0,884 dan pemakaian sesungguhnya sistem e-Audit sebesar 0,887. Hasil uji konsistensi internal diperkuat dengan menggunakan nilai cronbach's alpha. Suatu variabel dapat dinyatakan reliabel apabila memiliki nilai cronbach's alpha lebih besar dari 0,7 (Santosa 2018:82). Namun 0,6 sampai 0,7 masih dapat diterima. Nilai cronbach's alpha untuk relevan sebesar 0,682, terminologi sebesar 0,917, desain layar sebesar 0,923, kemudahan penggunaan persepsian sebesar 0,895, kegunaan persepsian sebesar 0,918, sikap untuk menggunakan sistem $e$-Audit sebesar 0,748 , niat perilaku menggunakan sistem $e$-Audit sebesar 0,803 dan pemakaian sesungguhnya sistem $e$-Audit sebesar 0,812 . Dengan demikian seluruh item pertanyaan yang digunakan untuk mengukur masing-masing variabel dalam penelitian ini dinyatakan reliabel. Hal ini dilihat dari nilai composite reliability dan cronbach's alpha diatas 0,7, dengan pertimbangan 0,6 masih dapat diterima.

Hasil uji validitas konvergen menunjukkan bahwa nilai AVE untuk relevan sebesar 0,757, terminologi sebesar 0,922, desain layar sebesar 0,927, kemudahan penggunaan persepsian sebesar 0,661 , kegunaan persepsian sebesar 0,708, sikap untuk menggunakan sistem $e$-Audit sebesar 0,669 , niat perilaku menggunakan sistem $e$-Audit sebesar 0,718 dan pemakaian sesungguhnya sistem $e$-Audit sebesar 0,723. Dengan demikian, masing-masing variabel menjelaskan lebih dari separuh varians berasal dari indikator-indikatornya karena masing-masing variabel memiliki nilai AVE lebih dari 0,5.

Hasil uji validitas diskriminan pada tingkat indikator disebut dengan cross loading menunjukkan nilai outer loading untuk indikator relevan sebesar 0,842 dan 0,897, terminologi sebesar 0,949 dan 0,971, desain layar sebesar 0,952 dan 0,974, kemudahan penggunaan persepsian sebesar 0,$775 ; 0,883 ; 0,752 ; 0,701 ; 0,881$; dan 0,868 , kegunaan persepsian sebesar 0,$905 ; 0,891 ; 0,844 ; 0,780$; 0,803 dan 0,820 , sikap untuk menggunakan sistem $e$-Audit sebesar 0,$707 ; 0,861$ dan 0,875 , niat perilaku menggunakan sistem $e$-Audit sebesar 0,$790 ; 0,854$ dan 0,896 , pemakaian sesungguhnya sistem e-Audit sebesar 0,847;0,841 dan 0,863. Dengan demikian, masing-masing indikator dari variabel yang digunakan dalam penelitian ini adalah valid, karena nilai outer loading masing-masing indikator diatas 0,7. Pada tingkat konstruk atau variabel, uji validitas diskriminan disebut dengan Fornell-Larcker criterion menunjukkan nilai untuk relevan sebesar 0,870, terminologi sebesar 0,960, desain layar sebesar 0,963, kemudahan penggunaan persepsian sebesar 0,813, kegunaan persepsian 
sebesar 0,842 , sikap untuk menggunakan sistem $e$-Audit sebesar 0,818 , niat perilaku menggunakan sistem $e$-Audit sebesar 0,848 dan pemakaian sesungguhnya sistem $e$-Audit sebesar 0,850 . Dengan demikian, variabel yang digunakan dalam penelitian ini adalah valid, karena nilai Fornell-Larcker criterion diatas 0,7 .

Setelah kriteria validitas dan reliabilitas terpenuhi, tahapan selanjutnya adalah melihat pengaruh signifikan antar variabel melalui pengujian hipotesis.

Tabel 1.

Hasil Uji Hipotesis

\begin{tabular}{|l|l|l|l|l|}
\hline & \multicolumn{1}{|c|}{ Koefisien Jalur } & T Statistics $(|\mathrm{O} / \mathrm{STDEV}|)$ & P Values & \multicolumn{1}{|c|}{ Kesimpulan } \\
\hline $\mathrm{R}$-> PU & 0,343 & 3,302 & 0,001 & Diterima \\
\hline R -> PEOU & 0,131 & 0,818 & 0,414 & Ditolak \\
\hline T -> PU & $-0,074$ & 0,617 & 0,538 & Ditolak \\
\hline T -> PEOU & 0,339 & 2,345 & 0,019 & Diterima \\
\hline SD -> PU & 0,073 & 0,586 & 0,558 & Ditolak \\
\hline SD -> PEOU & 0,133 & 0,703 & 0,483 & Ditolak \\
\hline PEOU -> PU & 0,498 & 4,357 & 0,000 & Diterima \\
\hline PEOU -> ATT & 0,046 & 0,204 & 0,838 & Ditolak \\
\hline PU -> ATT & 0,548 & 3,085 & 0,002 & Diterima \\
\hline PU -> BI & 0,335 & 2,296 & 0,022 & Diterima \\
\hline ATT -> BI & 0,385 & 2,931 & 0,004 & Diterima \\
\hline BI -> ASU & 0,660 & 6,335 & 0,000 & Diterima \\
\hline
\end{tabular}

Sumber: Output SmartPLS 3, data diolah 2019

Tabel 2.

$R$ Square

\begin{tabular}{|l|r|r|}
\hline & \multicolumn{1}{|c|}{$R$ Square } & $R$ Square Adjusted \\
\hline ASU & 0,436 & 0,426 \\
\hline ATT & 0,332 & 0,309 \\
\hline BI & 0,409 & 0,388 \\
\hline PEOU & 0,232 & 0,190 \\
\hline PU & 0,483 & 0,445 \\
\hline
\end{tabular}

Sumber: Output SmartPLS 3, data diolah (2019)

Berdasarkan tabel diatas diketahui bahwa pengaruh relevan (R) terhadap kegunaan persepsian (PU) menghasilkan nilai probabilitas (P) sebesar 0,001 dan $t_{\text {hitung }}$ sebesar 3,302. Nilai $\mathrm{P}$ tersebut $<0,05$ dan nilai $t_{\text {hitung }}>t_{\text {tabel }}$ atau $t_{\text {hitung }}>1,671$ sehingga dapat disimpulkan bahwa terdapat pengaruh relevan terhadap kegunaan persepsian (PU). Nilai koefisien jalur yang positif menunjukkan arah hubungan antara relevan dengan $\mathrm{PU}$ adalah positif. $\mathrm{Hal}$ ini berarti $\mathrm{H}_{1 \mathrm{a}}$ diterima.

Nilai $\mathrm{P}$ dan $\mathrm{t}_{\text {hitung }}$ pada hubungan antara relevan dan kemudahan penggunaan persepsian (PEOU) adalah 0,414 dan 0,818. Nilai $\mathrm{P}$ tersebut $>0,05$ dan nilai $\mathrm{t}_{\text {hitung }}<\mathrm{t}_{\text {tabel }}$ atau $\mathrm{t}_{\text {hitung }}<1,671$ menunjukkan bahwa tidak terdapat pengaruh relevan terhadap PEOU. Hal ini berarti $\mathrm{H}_{1 \mathrm{~b}}$ ditolak.

Pengaruh terminologi (T) terhadap PU menghasilkan nilai probabilitas $(\mathrm{P})$ sebesar 0,538, atau $>0,05$ dan nilai $\mathrm{t}_{\text {hitung }}$ sebesar 0,617 , atau $<1,671$ menunjukkan bahwa tidak terdapat pengaruh terminologi terhadap PU. Hal ini berarti $\mathrm{H}_{2 \mathrm{a}}$ ditolak.

Pengaruh terminologi $(\mathrm{T})$ terhadap PEOU, menghasilkan nilai $\mathrm{P}$ sebesar 0,019, atau $<0,05$ dan nilai $t_{\text {hitung }}$ sebesar 2,345, atau > 1,671 menunjukkan bahwa terdapat pengaruh terminologi (T) terhadap PEOU. Nilai koefisien jalur pada hubungan tersebut adalah positif menunjukkan bahwa pengaruh $\mathrm{T}$ terhadap PEOU adalah pengaruh positif. Hal ini berarti $\mathrm{H}_{2 \mathrm{~b}}$ diterima. 
Nilai $\mathrm{P}$ sebesar 0,558, atau $>0,05$ dan nilai $t_{\text {hitung }}$ sebesar 0,586, atau $<1,671$ pada hubungan antara desain layar (SD) dan PU, menunjukkan bahwa tidak terdapat pengaruh layar desain (SD) terhadap PU. Hal ini berarti $\mathrm{H}_{3 \mathrm{a}}$ ditolak.

Nilai P dan thitung pada hubungan antara desain layar (SD) dan PEOU adalah 0,483 dan 0,703. Nilai $\mathrm{P}$ tersebut $>0,05$ dan nilai $\mathrm{t}_{\text {hitung }}<1,671$ menunjukkan bahwa tidak terdapat pengaruh SD terhadap PEOU. Hal ini berarti $\mathrm{H}_{3 b}$ ditolak.

Pengaruh kemudahan penggunaan persepsian (PEOU) terhadap kegunaan persepsian (PU)

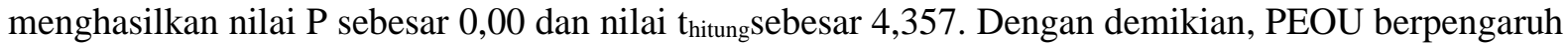
terhadap PU karena 0,00<0,05 dan 4,357> 1,671. Nilai koefisien jalur antara PEOU dan PU adalah positif menunjukkan bahwa pengaruh PEOU terhadap PU adalah pengaruh positif. Hal ini berarti $\mathrm{H}_{4}$ diterima.

Nilai $\mathrm{P}$ dan thitung pada hubungan antara PEOU dan Sikap menggunakan $e$-Audit (ATT) adalah 0,838 dan 0,204 . Nilai $\mathrm{P}$ tersebut $>0,05$ dan nilai $t_{\text {hitung }}<1,671$, yang berarti tidak terdapat pengaruh PEOU terhadap ATT. Hal ini berarti $\mathrm{H}_{5}$ ditolak.

Pengaruh PU terhadap ATT menghasilkan nilai $\mathrm{P}$ dan $\mathrm{t}_{\text {hitung }}$ sebesar 0,002 dan 3,085. Nilai $\mathrm{P}$ tersebut $<0,05$ dan nilai $t_{\text {hitung }}>1,671$ menunjukkan bahwa terdapat pengaruh PU terhadap ATT. Nilai koefisien jalur yang menunjukkan nilai positif berarti pengaruh PU terhadap ATT adalah pengaruh positif. Hal ini berarti $\mathrm{H}_{6}$ diterima.

Hubungan antara PU dan niat perilaku menggunakan e-Audit (BI) menghasilkan nilai $\mathrm{P}$ sebesar 0,022 atau nilai $\mathrm{P}<0,05$ dan $\mathrm{t}_{\text {hitung }}$ sebesar 2,296 atau $\mathrm{t}_{\text {hitung }}>1,671$. Dengan demikian, dapat disimpulkan terdapat pengaruh antara PU dan BI. Nilai koefisien jalur yang positif menunjukkan bahwa hubungan pengaruh PU terhadap BI adalah pengaruh positif. $\mathrm{Hal}$ ini berarti $\mathrm{H}_{7}$ diterima.

Pengaruh ATT terhadap BI menghasilkan nilai $\mathrm{P}$ sebesar 0,004 dan nilai $\mathrm{t}_{\text {hitung }}$ sebesar 2,931. Nilai $\mathrm{P}$ tersebut $<0,05$ dan nilai $\mathrm{t}_{\text {hitung }}>1,671$ menunjukkan bahwa terdapat pengaruh ATT terhadap BI. Pengaruh ATT terhadap BI adalah pengaruh positif karena nilai koefisien jalurnya adalah positif. $\mathrm{Hal}$ ini berarti $\mathrm{H}_{8}$ diterima.

Nilai $\mathrm{P}$ dan $\mathrm{t}_{\text {hitung }}$ pada hubungan antara $\mathrm{BI}$ dan pemakaian sesungguhnya $e$-Audit (ASU) adalah 0,000 dan 6,335. Nilai $P$ tersebut $<0,05$ dan nilai $t_{\text {hitung }}>1,671$ yang berarti terdapat pengaruh BI terhadap ASU. Pengaruh BI terhadap ASU adalah pengaruh positif, yang ditunjukkan dari nilai koefisien yang positif. Hal ini berarti $\mathrm{H}_{9}$ diterima.

Nilai Koefisien determinasi atau $R^{2}$ pada tabel 2 berkisar antara 0 sampai 1 . Hal ini menunjukkan bahwa terdapat pengaruh yang tinggi antara peubah laten eksogenus dan peubah laten endogenus.

\section{Pengaruh Relevan Terhadap Kegunaan Persepsian dan Kemudahan Penggunaan Persepsian}

Hasil uji hipotesis 1a menunjukkan relevan berpengaruh positif terhadap kegunaan persepsian. Dengan kata lain, sistem $e$-Audit menyediakan informasi yang relevan dengan tugas pemeriksa, sehingga meningkatkan kinerja pekerjaan dari pemeriksa. Hal ini mengindikasikan, semakin relevan informasi dalam sistem $e$-Audit dengan tugas pemeriksaan, maka akan meningkatkan kegunaan dari sistem $e$-Audit. Hasil penelitian ini sesuai dengan teori TAM. Menurut teori TAM relevan berpengaruh positif terhadap kegunaan persepsian.

Hasil penelitian ini mendukung hasil penelitian Hong et al (2002) dan Darsono (2005) yang menemukan bukti empiris bahwa relevan berpengaruh positif terhadap kegunaan persepsian. Hong et al (2002) berpendapat bahwa relevan berpengaruh positif terhadap kegunaan persepsian merupakan hal yang wajar, karena salah satu tujuan dari teknologi sistem informasi adalah untuk menyediakan dokumen atau informasi yang sesuai dengan kebutuhan pengguna. Kesesuaian informasi antara teknologi sistem informasi dan kebutuhan pengguna akan membuat sistem informasi berguna bagi pengguna.

Hasil uji hipotesis $1 \mathrm{~b}$ menunjukkan tidak terdapat pengaruh relevan terhadap kemudahan penggunaan persepsian. Dengan kata lain, sistem $e$-Audit menyediakan informasi yang relevan dengan tugas pemeriksa, sehingga membuat sistem e-Audit berguna bagi auditor, namun tidak membuat sistem e-Audit mudah untuk digunakan. Hal ini disebabkan oleh, para auditor BPK menganggap informasi dalam sistem $e$-Audit tidak sesuai dengan pekerjaan pemeriksaan. Ketidaksesuaian 
informasi dalam sistem $e$-Audit dengan tugas pemeriksaan membuat sistem $e$-Audit tidak mudah digunakan.

Hasil penelitian ini tidak sejalan dengan hasil penelitian Hong et al (2002) dan Darsono (2005) yang menemukan bukti empiris bahwa relevan berpengaruh positif terhadap kemudahan penggunaan persepsian. Namun, hasil penelitian ini mendukung hasil penelitian dari Wijaya dan Radhi (2004). Menurut Wijaya dan Radhi (2004), tidak berpengaruhnya relevan terhadap kemudahan penggunaan persepsian, disebabkan oleh informasi yang ada dalam teknologi sistem informasi tidak sesuai dengan kebutuhan dari pengguna, sehingga bagi pengguna teknologi sistem informasi tidak mudah untuk digunakan.

\section{Pengaruh Terminologi Terhadap Kegunaan Persepsian dan Kemudahan Penggunaan Persepsian}

Hasil uji hipotesis 2a menunjukkan terminologi tidak berpengaruh terhadap kegunaan persepsian. Tidak berpengaruhnya terminologi terhadap kegunaan persepsian, berarti terminologi yang ada dalam sistem $e$-Audit tidak membuat sistem $e$-Audit lebih berguna. Hal ini berarti kosakata, kalimat atau ungkapan yang ada dalam sistem $e$-Audit tidak sesuai dengan tugas pemeriksaan, sehingga membuat sistem e-Audit tidak meningkatkan kinerja pekerjaan dari auditor BPK RI Perwakilan Provinsi Sulawesi Utara.

Hasil temuan ini sejalan dengan hasil penelitian Hong et al (2002), namun tidak sejalan dengan hasil penelitian Darsono (2005) yang menemukan bukti empiris bahwa terminologi berpengaruh positif terhadap perceived usefulness. Menurut Hong et al (2002), ketidaksesuaian terminologi yang ada dalam sistem informasi mengurangi kegunaan dari sistem informasi.

Hasil uji hipotesis $2 \mathrm{~b}$ menunjukkan terminologi berpengaruh positif terhadap kemudahan penggunaan persepsian. Hal ini berarti, terminologi dalam sistem $e$-Audit memudahkan auditor dalam menggunakan sistem $e$-Audit. Dengan kata lain, semakin sesuai terminologi dalam sistem $e$-Audit dengan tugas pemeriksaan, maka semakin memudahkan auditor dalam menggunakan sistem $e$-Audit. Temuan ini mendukung teori TAM yang mengatakan bahwa terminologi berpengaruh positif terhadap kemudahan penggunaan persepsian.

Temuan dalam penelitian ini sesuai dengan hasil temuan yang dikemukakan oleh Hong et al (2002). Penelitian tersebut menemukan bukti, bahwa terminologi berpengaruh positif terhadap kemudahan penggunaan persepsian. Hong et al (2002) berpendapat bahwa terminologi merupakan bagian permukaan dari suatu sistem informasi. Oleh karena itu, bagian permukaan yang ramah terhadap pengguna akan membantu pengguna menggunakan sistem informasi lebih mudah. Terminologi yang digunakan pengguna untuk menggungkapkan kebutuhan informasi mereka, sesuai dengan terminologi yang ada dalam sistem informasi, sehingga mempermudah pengguna dalam menggunakan sistem informasi.

\section{Pengaruh Desain Layar Terhadap Kegunaan Persepsian dan Kemudahan Penggunaan Persepsian}

Hasil uji hipotesis 3a menunjukkan desain layar tidak berpengaruh terhadap kegunaan persepsian. Hal ini berarti, bagi auditor BPK RI Perwakilan Provinsi Sulawesi Utara, desain layar tidak membuat sistem $e$-Audit lebih berguna. Hal ini disebabkan oleh, tujuan adanya sistem $e$-Audit adalah untuk membantu para auditor dalam melaksanakan tugas pemeriksaan, sehingga desain layar sebagai antarmuka sistem $e$-Audit tidak berpengaruh terhadap kegunaan dari sistem $e$-Audit. Selain itu, kewajiban auditor untuk menggunakan sistem $e$-Audit tidak membuat desain layar menjadi faktor yang berpengaruh terhadap kegunaan persepsian.

Hasil penelitian ini mendukung hasil penelitian Hong et al (2002) dan Darsono (2005) yang menemukan bukti empiris bahwa desain layar tidak berpengaruh terhadap kegunaan persepsian. Menurut Hong et al (2002), seorang pengguna tidak akan menemukan suatu sistem informasi lebih bermanfaat hanya karena pengguna menyukai desain layar sistem informasi tersebut.

Hasil uji hipotesis $3 \mathrm{~b}$ menunjukkan desain layar tidak berpengaruh terhadap kemudahan penggunaan persepsian. Hal ini berarti, desain layar tidak membuat sistem $e$-Audit lebih mudah digunakan. Penyebab desain layar tidak berpengaruh terhadap kemudahan penggunaan persepsian, 
karena penggunaan sistem $e$-Audit diharuskan bagi setiap auditor, sehingga desain layar tidak menjadi faktor yang berpengaruh terhadap kemudahan penggunaan persepsian.

Hasil penelitian ini mendukung hasil penelitian Medyawati et al (2011), yang menemukan bukti empiris bahwa desain layar tidak berpengaruh terhadap kemudahan penggunaan sistem informasi. Berbeda dengan hasil penelitian Hong et al (2002) dan Darsono (2005), yang menemukan bukti empiris bahwa terdapat pengaruh positif desain layar terhadap kemudahan penggunaan sistem informasi. Menurut Medyawati et al (2011), desain layar dalam sistem informasi tidak mudah dimengerti oleh pengguna, karena desain layar tersebut terlalu formal dan kaku.

\section{Pengaruh Kemudahan Penggunaan Persepsian Terhadap Kegunaan Persepsian}

Hasil uji hipotesis 4 menunjukkan kemudahan penggunaan persepsian berpengaruh positif terhadap kegunaan persepsian. Hal ini berarti, bagi auditor BPK RI Perwakilan Provinsi Sulawesi Utara sistem e-Audit mudah untuk digunakan, sehingga meningkatkan kepercayaan auditor atas kegunaan dari sistem $e$-Audit. Dengan adanya kemudahan penggunaan persepsian yang dialami oleh auditor memberikan kepercayaan diri atas kemampuan mereka dalam memanfaatkan sistem $e$-Audit. Dengan kata lain, semakin tinggi kemudahan sistem $e$-Audit, maka akan semakin meningkatkan kegunaan dari sistem $e$-Audit.

Penelitian ini menguatkan teori TAM (Davis, 1989) yang menyatakan bahwa PEOU mempengaruhi PU. Hasil penelitian ini mendukung temuan penelitian-penelitian sebelumnya antara lain Lu et al (2005), Santoso (2012), Permana (2013), David (2013) dan Intan (2014). Menurut Lu, Yao dan Yu (2005), kemudahan penggunaan sistem informasi merupakan penggerak utama seorang pengguna mau menggunakan sistem informasi, karena semakin mudah suatu sistem informasi maka akan semakin meningkatkan kegunaan dari sistem informasi tersebut. Pengguna yang merasakan kemudahan penggunaan suatu sistem informasi, akan merasa sistem informasi tersebut berguna atau bermanfaat. Penelitian ini memberikan tambahan bukti empiris bahwa PEOU berpengaruh positif terhadap PU.

\section{Pengaruh Kemudahan Penggunaan Persespsian Terhadap Sikap Untuk Menggunakan Sistem e-Audit}

Berdasarkan hasil uji hipotesis 5 diketahui bahwa kemudahan penggunaan persepsian tidak memiliki pengaruh terhadap sikap menggunakan $e$-Audit. Tidak berpengaruhnya kemudahan penggunaan persepsian terhadap sikap menggunakan sistem $e$-Audit, berarti sistem $e$-Audit tidak mudah untuk digunakan. Dalam TAM dijelaskan bahwa suatu teknologi sistem informasi, jika mudah digunakan akan mendorong perasaan positif seseorang untuk menggunakan sistem teknologi informasi tersebut. Menurut David (2013) salah satu penyebab kemudahan penggunaan persepsian tidak berpengaruh terhadap sikap menggunakan $e$-Audit karena kurangnya sosialisasi dan pelatihan yang dilakukan oleh BPK.Selain itu, penyebab kemudahan penggunaan persepsian tidak mendorong auditor untuk menggunakan sistem $e$-Audit adalah kewajiban penggunaan sistem $e$-Audit membuat para auditor harus menggunakan sistem $e$-Audit, sekalipun sistem $e$-Audit tidak mudah untuk digunakan.

\section{Pengaruh Kegunaan Persepsian Terhadap Sikap Menggunakan Sistem $\boldsymbol{e}$-Audit}

Hasil pengujian hipotesis 6 menunjukkan kegunaan persepsian berpengaruh positif terhadap sikap menggunakan sistem $e$-Audit. Dengan kata lain, sistem $e$-Audit berguna dan dapat meningkatkan kinerja pekerjaan dari auditor di BPK RI Perwakilan Provinsi Sualwesi Utara, sehingga mendorong sikap auditor untuk menggunakan sistem $e$-Audit. Hal ini mengindikasikan, semakin tinggi kegunaan dari sistem $e$-Audit, maka akan semakin membentuk perasaan positif dan direfleksikan melalui sikap yang positif.

Penelitian ini menguatkan teori TAM yang mengatakan bahwa kegunaan sistem informasi adalah konstruk yang paling signifikan dan penting yang mempengaruhi sikap seseorang untuk menggunakan sistem $e$-Audit. Jika seseorang percaya bahwa sistem informasi dapat meningkatkan kinerja pekerjaannya dan berguna maka akan mendorong sikap seseorang untuk menggunakan sistem informasi tersebut. 
Hasil penelitin ini sejalan dengan hasil yang ditemukan oleh Permana (2013), David (2013), Karpriana (2013), Cahyaning (2016) bahwa kegunaan sistem informasi berpengaruh positif terhadap sikap untuk menggunakan teknologi sistem informasi. Pengguna yang merasakan manfaat dari penggunaan sistem informasi akan memunculkan sikap yang positif terhadap penggunaan sistem tersebut. Penelitian ini memberikan tambahan bukti empiris bahwa sistem informasi yang berguna akan mendorong sikap seseorang untuk menggunakan sistem informasi tersebut.

\section{Pengaruh Kegunaan Persepsian Terhadap Niat Perilaku Menggunakan Sistem $\boldsymbol{e}$-Audit}

Berdasarkan hasil uji hipotesis 7 menunjukkan kegunaan persepsian berpengaruh positif terhadap niat perilaku menggunakan sistem $e$-Audit. Hal ini berarti semakin tinggi manfaat yang di dapat auditor dalam penggunaan sistem $e$-Audit, maka semakin tinggi juga niat perilaku auditor untuk menggunakan sistem $e$-Audit. Hal ini mengindikasikan bahwa auditor percaya bahwa sistem $e$-Audit dapat meningkatkan kinerja pekerjaannya sehingga, akan meningkatkan keinginannya untuk menggunakan sistem $e$-Audit.

Temuan dalam penelitian ini mendukung hasil penelitian dari Hong et al (2002), Darsono (2005), Lu et al (2005), Karpriana (2013), Permana (2013), Surachman (2013), Intan (2014), Sondakh (2017). Penelitian-penelitian tersebut memberikan bukti empiris bahwa kegunaan persepsian berpengaruh positif terhadap niat perilaku menggunakan teknologi sistem informasi. Seseorang yang percaya bahwa suatu teknologi sistem informasi berguna dan merasakan hasil dari penggunaan sistem informasi tersebut akan meningkatkan niat perilaku seseorang untuk menggunakan sistem informasi tersebut. Namun, hasil penelitian ini tidak mendukung hasil penelitian David (2013) yang menemukan bukti empiris bahwa kegunaan persepsian tidak berpengaruh terhadap niat perilaku auditor BPK RI untuk menggunakan sistem $e$-Audit.

Hasil penelitian ini menguatkan teori TAM yang menyatakan, bahwa kegunaan sistem informasi merupakan konstruk yang paling signifikan dan penting yang mempengaruhi niat perilaku seseorang untuk menggunakan suatu teknologi sistem informasi. Oleh karena itu, hasil penelitian ini menjadi tambahan bukti pengaruh kegunaan sistem informasi terhadap niat perilaku menggunakan sistem informasi.

\section{Pengaruh Sikap Menggunakan Sistem $e$-Audit Terhadap Niat Perilaku Menggunakan Sistem $e$ - Audit}

Hasil pengujian hipotesis 8 menunjukkan sikap menggunakan sistem $e$-Audit berpengaruh positif terhadap niat perilaku menggunakan sistem e-Audit. Dengan kata lain, sikap untuk menggunakan sistem sebagai suatu penilaian terhadap dampak yang dialami seseorang bila menggunakan sistem informasi dalam pekerjaannya. Penerapan sistem $e$-Audit di BPK mengharuskan para auditor BPK RI Perwakilan Provinsi Sulawesi Utara untuk menjalankannya, dengan adanya kewajiban ini meningkatkan niat perilaku auditor untuk menggunakan sistem $e$-Audit.

Hasil penelitian ini sejalan dengan hasil penelitian sebelumnya oleh El-Gayar dan Moran (2007), David (2013), Permana (2013). Penelitian-penelitian tersebut menemukan bukti empiris bahwa sikap menggunakan suatu teknologi sistem informasi berpengaruh positif terhadap niat perilaku menggunakan teknologi sistem informasi. Seseorang yang memiliki perasaan positif terhadap teknologi sistem informasi, yang diartikan sebagai sikap oleh Davis (1989), maka orang tersebut akan meningkatkan niat perilaku untuk menggunakan teknologi sistem informasi. Penelitian ini juga menguatkan teori TAM yang menyebutkan bahwa sikap menggunakan sistem informasi berpengaruh positif terhadap niat perilaku menggunakan sistem informasi.

\section{Pengaruh Niat Perilaku Menggunakan Sistem e-Audit Terhadap Pemakaian Sesungguhnya Sistem $e$-Audit}

Berdasarkan hasil uji hipotesis 9 menunjukkan niat perilaku menggunakan sistem $e$-Audit berpengaruh positif terhadap pemakaian sesungguhnya sistem e-Audit. Hal ini berarti, niat perilaku auditor BPK RI Perwakilan Provinsi Sulawesi Utara untuk menggunakan sistem $e$-Audit dibuktikan dengan auditor menggunakan sistem $e$-Audit dalam melaksanakan tugas pemeriksaannya. Dengan 
kata lain, semakin tinggi niat perilaku auditor untuk menggunakan sistem $e$-Audit, semakin tinggi juga penggunaan sistem $e$-Audit oleh auditor.

Hasil temuan dalam penelitian ini mendukung hasil penelitian yang dikemukakan oleh Moon dan Kim (2001), Gardner dan Amoroso (2004) dan Intan (2014). Penelitian-penelitian tersebut menemukan bahwa niat perilaku menggunakan teknologi sistem informasi berpengaruh positif terhadap pemakaian sesungguhnya teknologi sistem informasi. Sistem yang mudah dan mampu memberikan manfaat terhadap seseorang akan menimbulkan niat yang positif terhadap sistem informasi tersebut yang akan berdampak pada pemakaian sistem informasi dalam intensitas dan frekuensi yang tinggi. Penelitian ini memberikan tambahan bukti bagi teori TAM. Teori ini menjelaskan bahwa niat perilaku berpengaruh positif terhadap pemakaian sesungguhnya suatu teknologi sistem informasi.

\section{Kesimpulan dan Saran} bahwa:

Berdasarkan hasil penelitian yang diperoleh dan pembahasan, maka dapat disimpulkan

1. Relevan berpengaruh positif terhadap kegunaan persepsian, terminologi dan desain layar tidak berpengaruh terhadap kegunaan persepsian.

2. Terminologi yang berpengaruh positif terhadap kemudahan penggunaan persepsian, relevan dan desain layar tidak berpengaruh terhadap kemudahan penggunaan persepsian.

3. Kemudahan penggunaan persepsianberpengaruh positif terhadap kegunaan persepsian.

4. Kemudahan penggunaan persepsiantidak berpengaruh terhadap sikap menggunakan sistem $e$ Audit.

5. Kegunaan persepsian berpengaruh positif terhadap sikap menggunakan sistem $e$-Audit.

6. Kegunaan persepsianberpengaruh positif terhadap niat perilaku menggunakan sistem $e$-Audit.

7. Sikap menggunakan sistem $e$-Audit berpengaruh positif terhadap niat perilaku menggunakan sistem $e$-Audit.

8. Niat perilaku menggunakan sistem e-Audit berpengaruh positif terhadap pemakaian sesungguhnya sistem $e$-Audit.

Hasil penelitian ini membuktikan bahwa 7 hipotesis yang diterima dari 12 hipotesis yang diajukan. Dilihat dari dua faktor utama teori TAM yaitu kegunaan persepsian dan kemudahan penggunaan persepsian. Faktor yang berpengaruh terhadap penggunaan atau pemakaian sesungguhnya sistem $e$-Audit adalah kegunaan persepsian. Kegunaan persepsian berpengaruh terhadap pemakaian sesungguhnya melalui sikap menggunakan sistem $e$-Audit dan niat perilaku menggunakan sistem $e$-Audit. Sedangkan, variabel eksternal yang berpengaruh terhadap pemakaian sesungguhnya sistem $e$-Audit adalah variabel eksternal relevan melalui kegunaan persepsian dan variabel eksternal terminologi melalui kemudahan penggunaan persepsian.

Adapun saran yang disampaikan dalam penelitian ini adalah sebagai berikut:

1. Bagi BPK RI agar sistem $e$-Audit dapat diterapkan $100 \%$ dalam tugas pemeriksaan auditor maka kegunaan dari sistem $e$-Audit menjadi perhatian utama. Berdasarkan hasil penelitian yang menunjukkan bahwa kegunaan persepsian berpengaruh terhadap sikap menggunakan $e$ Audit membuktikan bahwa auditor BPK RI Perwakilan Provinsi Sulawesi Utara akan meningkatkan penggunaan sistem $e$-Audit karena auditor menganggap sistem $e$-Audit berguna daripada mudah digunakan. Oleh karena itu, dalam pengembangan sistem $e$-Audit faktor kegunaan harus diperhatikan oleh BPK RI.

2. Berdasarkan hasil penelitian, variabel eksternal karakteristik sistem berpengaruh terhadap kegunaan persepsian adalah relevan. Hal ini membuktikan bahwa informasi yang ada dalam sistem $e$-Audit relevan dengan tugas pemeriksaan, sehingga sistem e-Audit dapat meningkatkan kinerja pekerjaan dari auditor BPK RI Perwakilan Provinsi Sulawesi Utara. Oleh karena itu, dalam mengembangkan sistem e-Audit, BPK RI harus memperhatikan relevansi informasi yang ada dalam sistem $e$-Audit dengan tugas pemeriksaan.

3. Hasil penelitian yang mengatakan bahwa, variabel eksternal karakteristik sistem berpengaruh terhadap kemudahan penggunaan persepsianadalah terminologi. Hal ini berarti, terminologi yang ada dalam sistem $e$-Audit membantu memudahkan auditor dalam menggunakan sistem 
$e$-Audit. Oleh karena itu, dalam pengembangan sistem $e$-Audit, faktor terminologi harus diperhatikan oleh BPK RI.

4. Penelitian ini memiliki keterbatasan seperti jumlah sampel yang sedikit karena penelitian dilakukan hanya di satu daerah perwakilan BPK RI yaitu Provinsi Sulawesi Utara, pada penelitian berikutnya diharapkan dapat menambah jumlah sampel dengan melakukan penelitian di beberapa daerah perwakilan BPK RI atau melakukan perbandingan penelitian antara perwakilan daerah BPK RI yang satu dengan daerah lainnya.

5. Hasil penelitian menunjukkan kemudahan penggunaan persepsiantidak berpengaruh terhadap sikap menggunakan sistem $e$-Audit. Hal ini berarti, sistem $e$-Audit tidak membuat pekerjaan pemeriksaan menjadi mudah, sehingga tidak mendorong auditor untuk menggunakan sistem $e$-Audit. Pada penelitian selanjutnya, diharapkan dapat melakukan penelitian mengapa sistem $e$-Audit tidak mudah digunakan. Penelitian selanjutanya dapat menggunakan metode penelitan yang berbeda, yaitu kualitatif. Sehingga dapat diketahui secara langsung kepada auditor kendala yang dihadapi berkaitan dengan pengembangan sistem $e$-Audit.

\section{Daftar Pustaka}

Cahyaning, E. K. (2016). Evaluasi Penerimaan Sistem Teknologi Informasi Branch Delivery System Di Kalangan Perbankan Dengan Menggunakan Technology Acceptance Model (TAM) (Doctoral dissertation, Universitas Gadjah Mada).

Darsono, L. I. (2005). Examining information technology acceptance by individual professionals. Gadjah Mada International Journal of Business, 7(2), 155-178.

David, P. (2013). Analisis Penerimaan Penerapan E-Audit dengan Menggunakan Technology Acceptance Model (TAM): Studi pada Badan Pemeriksa Keuangan Republik Indonesia (Doctoral dissertation, Universitas Gadjah Mada).

Davis, F. D. (1989). Perceived usefulness, perceived ease of use, and user acceptance of information technology. MIS quarterly, 319-340.

Davis, F. D. (1993). User acceptance of information technology: system characteristics, user perceptions and behavioral impacts. International journal of man-machine studies, 38(3), 475-487.

El-Gayar, O., \& Moran, M. (2007). Examining students' acceptance of tablet PC using TAM. Issues in Information Systems, 8(1), 167-172.Hartono, J. (2007). Sistem Informasi Keperilakuan. Yogyakarta: Andi Offset.

Gardner, C., \& Amoroso, D. L. (2004, January). Development of an instrument to measure the acceptance of internet technology by consumers. In 37th Annual Hawaii International Conference on System Sciences, 2004. Proceedings of the (pp. 10-pp). IEEE.

Hartono, J. (2005). Analisis dan Desain Sistem Informasi: Pendekatan Terstruktur, Teori dan Praktik Aplikasi Bisnis. Yogyakarta: Andi Offset.

Hartono, J. (2007). Sistem Informasi Keperilakuan. Yogyakarta: Andi Offset.

Hartono, J. (2008). Sistem Informasi Keperilakuan: Edisi Revisi. Yogayakarta: Andi Offset.

Hong, W., Thong, J. Y., Wong, W. M., \& Tam, K. Y. (2002). Determinants of user acceptance of digital libraries: an empirical examination of individual differences and system characteristics. Journal of Management Information Systems, 18(3), 97-124.

Intan, R.A. (2014). Pengaruh Faktor-Faktor Internal Dan Eksternal Terhadap Penggunaan ECommerce Pada Usaha Kecil Menengah (UKM) (Doctoral dissertation, Universitas Gadjah Mada).

Karpriana, A. P. (2013). Faktor-Faktor Yang Mempengaruhi Pengguna Untuk Mengadopsi Teknologi Komputasi Awan Di Yogyakarta. (Doctoral dissertation, Universitas Gadjah Mada).

Kementerian Pendayagunaan Aparatur Negara dan Reformasi Birokrasi. (2019). https://www.menpan.go.id/site/reformasi-birokrasi/makna-dan-tujuan.

Lim, K. H., Benbasat, I., \& Todd, P. A. (1996). An experimental investigation of the interactive effects of interface style, instructions, and task familiarity on user performance. ACM Transactions on Computer-Human Interaction (TOCHI), 3(1), 1-37. 
Lu, J., Yao, J. E., \& Yu, C. S. (2005). Personal innovativeness, social influences and adoption of wireless Internet services via mobile technology. The Journal of Strategic Information Systems, 14(3), 245-268.

Marchionini, G., Plaisant, C., \& Komlodi, A. (1998). Interfaces and tools for the Library of Congress national digital library program. Information processing \& management, 34(5), 535-555.

Mathieson, K. (1991). Predicting user intentions: comparing the technology acceptance model with the theory of planned behavior. Information systems research, 2(3), 173-191.

Medyawati, H., Christiyanti, M., \& Yunanto, M. (2011). E-banking adoption analysis using technology acceptance model (TAM): Empirical study of bank customers in Bekasi city. International Co/! ference 011llnovatioll, Mallagemellt and Service, 14.

Moon, J. W., \& Kim, Y. G. (2001). Extending the TAM for a World-Wide-Web context. Information \& management, 38(4), 217-230.

Permana, L. (2013). Analisis Faktor-Faktor Penerimaan Aplikasi Sintesis Pada Fakultas Ekonomika Dan Bisnis Universitas Gadjah Mada Berdasarkan Peran Motivasi Extrinsic Dan Intrinsic (Doctoral dissertation, Universitas Gadjah Mada).

Purnomo, Hadi. (2011). BPK Perkuat Pemeriksaan Melalui E-audit-Selayang Pandang E-audit. BPK RI, Juni 25, 2019. http://www.bpk.go.id/page/selayang-pandang-e-audit.

Purnomo, Hadi. (2012). BPK Bersama Pemda Sulawesi Utara Sepakati E-audit. BPK RI. Juli 03, 2019. http://www.bpk.go.id/news/bpk-bersama-pemda-sulawesi-utara-sepakati-e-audit.

Santosa, Paulus I. (2018). Metode Penelitian Kuantitatif Pengembangan Hipotesis dan Pengujiannya Menggunakan SmartPLS. Yogyakarta: Andi Offset.

Santoso, B. (2012). Pengaruh perceived usefulness, perceived ease of use, dan perceived enjoyment terhadap penerimaan teknologi informasi (Studi Empiris di Kabupaten Sragen). Jurnal Studi Akuntansi Indonesia, 1-15.

Sondakh, J. J. (2017). Prediksi Minat Perilaku Menggunakan Jasa Pajak Elektronik: Analisis Faktor Konfirmatori. InFestasi, 13(2), 321-333.

Surachman, A. (2013). Analisis Pengaruh Perceived Usefulness, Perceived Ease of Use, Subjective Norm, Mobility, dan Use Situation terhadap Niat Individu dalam menggunakan MLibrary (Doctoral dissertation, Universitas Gadjah Mada).

Wijaya, P. S. M., \& Radhi, F. (2004). Pengaruh Perbedaan Individual dan Karakteristik Sistem Terhadap Penerimaan Penggunaan Teknologi Informasi: Replikasi Model di Bidang E-Job Vacancies. Journal of Indonesian Economy and Business, 19(3). 